\title{
RECLAMATION OF DAMAGED AGRICULTURAL LAND: AN EXAMPLE OF THE SAMARA REGION
}

\author{
Khasaev Gabibulla', Vasilieva Dariya ${ }^{1}$, Vlasov Alexandr' ${ }^{1}$, Parsova Velta ${ }^{2}$ \\ ${ }^{1}$ Samara State University of Economics (Russia), \\ ${ }^{2}$ Latvia University of Life Sciences and Technologies
}

\begin{abstract}
The issues of environmental protection, prevention of degradation and reclamation of damaged land are currently very significant and relevant. As damaged land has been observed the land where low productivity and low economic potential have arisen and natural productivity of ecosystems is changed due to human-caused activities. The nature and extent of the violation depends on the type, depth and duration of anthropogenic impact, on adopted system of work organization and the conditions of the environment.

Black soil dominates in the soil cover in Samara region, therefore there has been developed agricultural production. However there are located large oilfields and gas fields, which are under active exploitation and reduction of vegetation, dumping technological sites, laying trenches for pipelines, etc. have been noticed, which leads to formation of technogenic soils, damaged land cover, loss of soil fertility and land use type change. There special restoration measure - reclamation should be putted into practice on the territory of all categories of land, but especially on agricultural land.

The aim of the article is to study the situation with damaged agricultural land in Samara region of Russia and to develop scientifically based proposals for regeneration of its fertility after reclamation measures. The problems of pollution of agricultural land in the region have been investigated, main sources and types of pollution have been analysed, as well as legal, methodological and environmental protection documents on land reclamation have been studied. The peculiarities of reclamation of land on federal, municipal and property level have been considered. The article presents measures for reclamation of the land on the example of natural monopolies in the territory of the Samara region

Key words: agricultural land, damaged land, land degradation, prevention of degradation, reclamation.
\end{abstract}

\section{Introduction}

The issues of environmental protection, prevention of land degradation, as well as recultivation of disturbed land currently are very significant and relevant. The term "disturbed land" includes land on which productivity of natural ecosystems has been changed as a result of economic activity. The nature and extent of the violation depends on the type, depth and duration of anthropogenic impact, on adopted system of work organization and the general situation of environment. On the territory of Russian Federation, as result of long-term intense anthropogenic impact of industrial enterprises of different profiles, there are large areas of disturbed land with various environmental changes (Ponomarev, Kaplunov et al., 2014; Smetanin, 2004).

Land use should be based on the following principles: preservation of fertile soils as a non-renewable natural resource used for agriculture and forestry; preservation of agricultural land areas as limited resources of exceptional value, improvement of their quality and productivity; etc. (Aleknavičius P., Aleknavičius M., 2016). Non-compliance with these principles inevitably leads to land degradation, which is a pressing issue for many countries (Pomelov A., 2014).

The purpose of the article is to study disturbed agricultural land and possibility of restoring their fertility after reclamation.

In order to achieve this goal, the following tasks were set:

- according to the analysis of statistical reports of the ministries of Samara region, Rosprirodnadzor, Rosresstra, etc., to study the dynamics of the agricultural land in the region and the development of reclamation;

- on an example of the project on rehabilitation of the disturbed lands at unapproved working out of building minerals, to consider works which are spent at recultivation of the earths in the Samara region;

- to study the modern system of land resources management at the federal and regional levels, to identify the shortcomings of this system and to propose ways of solving the problem.

In the Samara region, which is located in the southeast of the European territory of Russia in the Middle Volga region, black soil dominates in the soil cover, therefore the region has developed agricultural production. The area of agricultural land in Samara region is 4067 thousand hectares (on 
01.01 .18 .) or $76 \%$ of total area of region. Arable land occupies 2.8 thousand hectares or $70 \%$ of total area of agricultural land (State report..., 2018).

On territory of region there are large gas and oil fields, which are being actively investigated and developed, as well as repair and restoration works, leading to oil spill. Large number of oil and gas pipelines on various levels passes through the territory of the region. In addition, solid mineral deposits (sand, limestone, chalk, marl, sandstone, shale, etc.) are being utilized. Mining is accompanied by the reduction of vegetation, arrangement of dumping sites, trenches for pipelines, etc., which leads to formation of man-made (technogenic) soils, to disturbed land cover, loss of soil fertility and land use change (Voronin, Vlasov et.al., 2013).

To prevent and correct negative effects of technogenic activities, it is necessary to carry out reclamation of the land (GOST 17.5.3.04-83, 1983). Reclamation is a complex of works on the restoration of disturbed land, fertility of which was lost as a result of economic or other activities (GOST 17.4.3.04-85, 1985; Recommendations..., 1983). It takes place on the territory of all categories of land, but it is very important on agricultural land (Collection..., 1987; The main provisions... 1995; On land reclamation..., 1994).

\section{Methodology of research and materials}

The statistical data of annual reports of Ministry of Forestry, Environmental Protection and Nature Management, of Federal Service for State Registration Office, Cadastre and Cartography (Rosreestra) regarding Samara Region on the state of the environment and natural resources and on the status and use of land have been reviewed.

Simple methods of mathematical calculations based on statistical reports were used to study the changes in the area of damaged lands by years, and methods of scientific analysis of literary sources were used.

\section{Discussions and results}

Area of agricultural land in recent years has been reduced annually due to its transfer to other categories of land, usually as a result of urbanization and development, as well as due to arrangement of linear objects. At the same time, agricultural land should be subject to special protection, because it has been used systematically for production of agricultural products. In recent years the area occupied by agricultural land in the Samara Region has not changed significantly (Table 1).

Characteristic of agricultural land in Samara region

Table 1

\begin{tabular}{|l|c|c|c|c|}
\hline \multicolumn{1}{|c|}{ Type of land use } & \multicolumn{4}{c|}{ Area } \\
\cline { 2 - 5 } & $\mathbf{2 0 1 0}$ & $\mathbf{2 0 1 3}$ & $\mathbf{2 0 1 6}$ & $\mathbf{2 0 1 7}$ \\
\hline Agricultural land, thousand hectares & 4089.4 & 4070.1 & 4067.4 & 4067.2 \\
\hline Agricultural land of total area of Samara region, \% & 74.7 & 74.7 & 74.6 & 74.6 \\
\hline Arable land of total area of agricultural land, \% & 73.7 & 73.4 & 73.4 & 73.5 \\
\hline Fallow land of total area of agricultural land, \% & 2.4 & 2.6 & 2.6 & 2.6 \\
\hline $\begin{array}{l}\text { Arable land, transformed from previously unused } \\
\text { land, thousand hectares }\end{array}$ & $\mathrm{X}$ & $\mathrm{X}$ & 7 & 3 \\
\hline
\end{tabular}

Source: own elaboration, using statistical data of annual reports

On the territory of region orchards occupy an area of 42 thousand hectares, meadows - 67 thousand hectares, pastures - 847 thousand hectares, irrigated land - 141 thousand hectares. Area of mentioned types of land use also practically did not change over the last 10 years.

Land users in Russia are obligated to submit annually statistical reports, which contain information on recultivation of the land, removal and use of layer of fertile soil. This report should be submitted by land users or organizations engaged in construction, amelioration, forest exploitation, survey, as well as producing industrial, construction and solid household waste.

According to the statistical reports on reclamation of the land, on 01.01.2018 area of damaged land in Samara region was 1.8 thousand hectares. Volume of removed fertile layer of soil was about 4 million $\mathrm{m}^{3}$. Table 2 shows the dynamics of changes in the area of damaged land in the Samara region over past three years (Table 2). Official statistical data about removed soil used for land reclamation purposes was not available. 
Area of damaged agricultural land in Samara region

\begin{tabular}{|l|c|c|c|}
\hline \multicolumn{2}{|l|}{} & \multicolumn{3}{|c|}{ Year } \\
\cline { 2 - 4 } & $\mathbf{2 0 1 5}$ & $\mathbf{2 0 1 6}$ & $\mathbf{2 0 1 7}$ \\
\hline Area of damaged land, ha & 1970 & 2329 & 1421 \\
\hline $\begin{array}{l}\text { Land involved in turnover of agricultural land after } \\
\text { recultivation, ha }\end{array}$ & $\mathrm{X}$ & 529 & 1020 \\
\hline Removed fertile layer of soil, ha & 1970 & 2254 & 1374 \\
\hline Removed soil used for land reclamation, thousand m & 7058 & 5590 & 25690 \\
\hline $\begin{array}{l}\text { Fertility of soil of unproductive land improved using } \\
\text { removed soil, ha }\end{array}$ & $\mathrm{X}$ & $\mathrm{X}$ & 6 \\
\hline
\end{tabular}

Source: own elaboration, using statistical data of annual reports

The data show that in the Samara region over the past three years the area of damaged land changed. As positive measure should be noted that area involved in the turnover after the reclamation of agricultural land is growing. In 2017 started use of fertile upper humus-accumulative soil horizon to improve the properties of low-productive land, which was not observed in previous years. There was a rapid increase (about 4.5 times) of use of fertile soil for land reclamation (Report ..., 2018; State report ..., 2018).

On territory of Samara region there is an acute need for land reclamation (Voronin, Vlasov, Vasilieva, 2013). Development of land reclamation projects is an obligatory stage in the preparation of project documentation for construction of roads, power lines, oil pipelines, gas pipelines, railway lines and other facilities, as well as for the transformation of agricultural land to another category.

The cases of frequent occurrence of non-observance of environmental legislation, is illegal, unauthorized utilization of mineral resources (sand, gravel, etc.) for economic needs on agricultural land (Fig. 1).

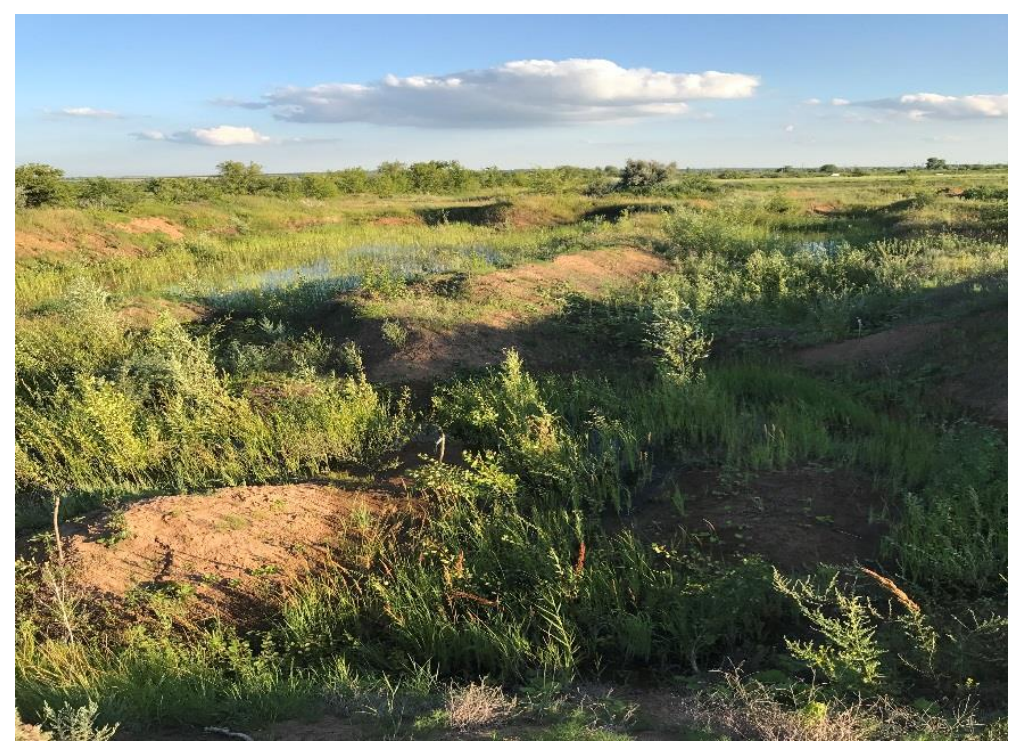

Fig.1. Appearance of damaged land in case of illegal utilization of mineral resources

As a rule, in this case reclamation project should to provide environmental aspect of remediation. Chosen direction of reclamation is governed by the fact that such project is developed not for the entire land plot, but only for utilised territory, where shape of this territory is obtained by topographic vertical surveying.

At the site of utilization of mineral resources is going on formation of disturbed land, overgrown with weeds, often swamped, with reed-sedge vegetation or filled with water in case of close occurrence of groundwater.

Reclamation is carried out gradually in two stages: technical and biological (GOST 17.5.3.04-83, 1983). For technical stage the master plan for restoration of disturbed land should be developed. The 
technical stage includes formation of technogenic landscape on worked-out areas in order to create the relief that smoothly goes down with adjacent territory of optimal geometric parameters and favourable conditions for using the site for its intended purpose by flattening the pit walls (slopes), partially raising the bottom of the pit, carrying out levelling of territory, strewing fertile layer of soil, etc. Carrying out the technical stage of recultivation the layer of fertile soil should be removed depending on soil fertility level and main soil property indicators. The depth of the fertile black soil layer is usually determined to the depth of the humus horizon $(\mathrm{A}+\mathrm{AB})$. At the technical stage it is necessary to cut the upper soil horizon about $0.5 \mathrm{~m}$ deep, dump the grooves and make rough surface levelling. After completion of the work the fertile soil layer should be dispersed on formed relief for seeding of perennial grasses (Ponomarev, Kaplunov et al., 2014).

The biological stage includes complex of agrotechnical and phytomeliory measures in order to restore agrophysical, agro-chemical, biochemical, and other soil properties. Biological reclamation is subject to land used in agricultural production. On such disturbed land an accelerated seeding of perennial grasses should be carried out, which is the most effective method of improvement of the sites with strewed soil. The minimum term of a biological stage of recultivation (ameliorative period) is 1 year. In case of restoration of land for pasture the ameliorative period of restoration of fertility of the applied fertile layer is 3 years. Recultivation is carried out using conventional agrotechnical measures, including pre-sowing tillage, application of organic and mineral fertilizers, sowing of perennial grass seeds, etc. During this period measures to preserve strewed soil layer from erosion, to maintain its biological activity, soil structure and air-water regime, as well as the accumulation of organic matter and nitrogen in the soil should be used.

The reclamation project should provide creation of sustainable grass stand. Grass mixtures sown on the reclaimed land protect the soil from erosion and give high yields. Very important is selection of proper species of leguminous plants and perennial cereal grasses and their mixtures. It has been accepted - if mixed crops of perennial grasses belong to different families and biological groups, moisture and nutrients are more fully used, because their root systems are distributed in different layers of soil. In addition, grass mixtures of several types of perennial grasses are more sustainable than pure crops. As a rule, the presence of strewed soils increases the feasibility of erosion processes, so it is necessary to carefully select certain types of perennial grasses and their mixtures. Sown grass mixture should create a closed slam and strong turf. Sowing should be done in well prepared and moist soil. Compulsory agrotechnical method should be rolling up with ragged rollers before and after sowing. It helps to level the soil surface and improve work into the ground of seeds.

To restore damaged fertile soil layer and soil biota, it is necessary to apply increased doses of organic and mineral fertilizers. Especially effective is the application of organic fertilizers in addition to plant leftovers. Fertilizers improve the water-physical properties of soil, enrich the soil with organic matter, improve water and air permeability of surface horizons and contribute to enhanced release of carbon dioxide during decomposition of dead organic matter and plant respiration. Grazing on restored pasture (up to 4 years), also hay mowing ( 2 - 3 years) before strong turf has been formed is not recommended.

Another type of technogenic impacts on the territory of the Samara region is construction of infrastructure objects for operation of oil producing wells. It also requires preparation of project and reclamation of disturbed land. Often the technology of biological reclamation of disturbed land for fodder land has been applied. In case of construction of oil wells appears necessity of land acquisition in short-term lease for period of construction and land reclamation (temporary allotment) and long term lease for period of operation of facilities (permanent allotment).

Control over implementation of measures for the preservation and reproduction of fertility of agricultural land is delegated to Federal Service for Veterinary and Phytosanitary Supervision (Rosselkhoznadzor) and the Federal Service for Supervision of Natural Resources (Rosprirodnadzor). Rosselkhoznadzor on agricultural land carry out the control over:

- conservation and restoration of fertility of agricultural land, including reclaimed land;

- prevention of unauthorized removal, displacement and destruction of topsoil and damage of the land as result of mismanagement of pesticides, agricultural chemicals or other hazardous to human health and the environment substances and wastes of production and consumption.

Rosprirodnadzor carry out the monitoring of:

- land reclamation after exploitation of mineral deposits, construction, amelioration, logging, etc.;

- improvement of land properties and soil protection from wind and water erosion;

- prevention of other processes worsening qualitative properties of the land. 
Rosprirodnadzor in the Samara region in 2018 as land control conducted 39 inspections. The main violations identified during inspections was unauthorized removal or movement of the fertile soil layer; destruction of a fertile layer of soil, as well as damage to land as a result of violation of the rules for handling pesticides and agrochemicals or other substances hazardous to human health and the environment, production and consumption waste.

After reclamation damaged land by the Permanent Commission on land reclamation, appointed by the municipal district administration should be transferred to land users, restoration of soil fertility should be confirmed. After completion of land reclamation, land should be classified to the relevant types of land use. In practice, the complex of land reclamation works often has been not fully implemented, while environmental deteriorates have been accumulated.

Thus, on the studied example of disturbed lands reclamation at unauthorized development of construction minerals in Samara region the progress of reclamation works was given. In the region the volume of these works is gradually increasing, after which the areas of agricultural lands are involved in circulation. The main way to solve the problem of reducing the area of disturbed lands is to improve the legal framework for land resources management, and in particular, to improve the mechanisms of land control. As in the Russian Federation at the federal level there is no single body for land resources management, these functions are divided into different ministries and federal agencies.

\section{Conclusions and proposals}

Summarizing the received information it is possible to draw a conclusion that the problem of recultivation of the disturbed lands is actual for regions with the developed industry and high density of the population to which the Samara region belongs. The difficulty in solving this problem is primarily due to shortcomings in environmental and land legislation at both the federal and regional levels.

Over past three years in Samara region the area of disturbed land was $1.4-2.3$ thousand hectares. At the same time, after recultivation yearly 500 - 100 hectares of agricultural land were involved in production. In 2017 started use of fertile soil layer for improvement of unproductive land, which was not observed in previous years. Use of fertile soil for land reclamation increased very fast, from 5.5 thousand $\mathrm{m}^{3}$ in 2016 to 25.7 thousand $\mathrm{m}^{3}$ in 2017 .

An important issue is development of regulatory framework in order to improve control over land reclamation, as well as creation of a single authority in land management sphere in Russian Federation.

\section{References}

1. Aleknavičius P., Aleknavičius M. The legal basis of land management in agricultural areas. Proceedings of scientific methodical conference „Baltic Surveying'16”. Jelgava, 2016. P. 5-13

2. Collection of enlarged standards for the costs of reclamation of disturbed land. (1987). Moscow, Gizr Publishing. $40 \mathrm{p}$.

3. GOST 17.5.3.04-83. Protection of Nature. Land. General requirements for land reclamation (1983) Moscow, Publishing Standards. $8 \mathrm{p}$.

4. GOST 17.4.3.04-85 "Nature protection. Soils. General requirements for the control and protection from pollution. (1985) Moscow, Publishing Standards $12 \mathrm{p}$.

5. On land reclamation, removal, conservation and rational use of the fertile soil layer (1994). Resolution of the Government of the Russian Federation № 140. Moscow, https://base.garant.ru

6. Ponomarev V.S., Kaplunov V.Yu., Ponomareva E.S., Konev I.A. (2014) On the recultivation of disturbed lands and their landscape cultivation during the liquidation of mines and cuts. Monitoring. Science and technology. №2 (19). pp. 46-53

7. Pomelov A. Land management against land/real estate degradation. Baltic Surveying. International scientific journal. 2014. Volume 1. P. 60-66.

8. Recommendations on the removal of the fertile soil layer in the production of mining, construction and other works. (1983). Moscow, Kolos Publishing. 39 p.

9. Report on the state and use of land in the Samara region in 2017. (2018) Department of the Federal Service for State Registration, Cadastre and Cartography of the Samara region. Samara. https://rosreestr.ru

10. Smetanin V.I. (2004) Land reclamation: a review of technology. Russian Ecology and Industry. pp. $42-45$

11. State report on the state of the environment and natural resources in the Samara region in 2017. Ministry of Forestry, Environment Protection and Nature Management of Samara Region. Samara. 2018. http://www.priroda.samregion.ru 
12. The main provisions on land reclamation, removal, conservation and rational use of fertile soil. (1995) Order of the Ministry of Natural Resources and Environment of the Russian Federation and Roskomzem № 525/67. http://docs.cntd.ru/document/901751620

13. Voronin V.V., Vlasov A.G., Vasilieva D.I. (2013) Structure and assessment of the quality of lands in the Samara region. Problems of regional ecology, Volume 4. p. 109-116.

14. Voronin V.V., Vlasov A.G., Vasilieva D.I., Most E.S. (2013) Ecological condition and quality of lands in the Samara region. Ecology of urbanized territories. Volume 4, p. 76-86.

Information about authors:

Habibulla Khasaev. Doctor of Economic Sciences, Prof., Rector of Samara State University of Economics. Address: Russia, 443090, Samara, Soviet Army street 141, phone +7 (846)-933-88-88, e-mail: rector@sseu.ru

Alexander Vlasov. PhD, Head of the Department of Land management and cadastre of Samara State University of Economics. Address: Russia, 443090, Samara, Soviet Army street 141, phone +7(937) 799-08-86, e-mail: kafzik@yandex.ru

Darya Vasilieva. PhD, Associate Professor of the Department of Land management and cadastre of Samara State University of Economics. Address: Russia, 443090, Samara, Soviet Army street 141, phone +7(927) 20030-78, e-mail: vasilievadi@mail.ru

Velta Parsova. Dr.oec., professor, Department of Land Management and Geodesy of Latvia University of Life Sciences and Technologies. Address: 19, Akademijas str., Jelgava, LV-3001, phone: +371 29118285, e-mail: $\underline{\text { velta@parsova.lv }}$ 